Newfoundland and Labrador Studies

\title{
Michelle Butler Hallett. Constant Nobody
}

\section{Nathan Elliott}

Volume 36, numéro 1, 2021

URI : https://id.erudit.org/iderudit/1082217ar

DOI : https://doi.org/10.7202/1082217ar

Aller au sommaire du numéro

Éditeur(s)

Faculty of Arts, Memorial University

ISSN

1719-1726 (imprimé)

1715-1430 (numérique)

Découvrir la revue

Citer ce compte rendu

Elliott, N. (2021). Compte rendu de [Michelle Butler Hallett. Constant Nobody]. Newfoundland and Labrador Studies, 36(1), 134-137.

https://doi.org/10.7202/1082217ar d'utilisation que vous pouvez consulter en ligne.

https://apropos.erudit.org/fr/usagers/politique-dutilisation/ 
Michelle Butler Hallett. Constant Nobody. Fredericton, NB: Goose Lane Editions, 2021. ISBN 978-1-77310-157-6

Almost two and half centuries ago, England's circulating libraries the Regency-era equivalent of Netflix - discovered a cash generator. Library subscribers could not get enough of The Monk and The Mysteries of Udolpho: the potent mix of danger and sex - often in the form of rape and incest - always brought readers back looking for more. Cultural critics fretted about the destructive effect of these novels on society as a whole, especially when - gasp! - a Member of Parliament (Matthew "Monk" Lewis) had penned such a nasty thing. Jane Austen satirized the genre in Northanger Abbey, yet she saved her real mockery for the social panic and made it clear she was an aficionado of these trashy novels herself. The booksellers found ways to keep capitalizing: they bound the novels — always about girls being locked up by evil Catholic (or Jewish or Muslim) uncles and fathers during the Middle Ages (or the English Civil War) in the middle of the Alps (or Spain, or Ireland) - in special red binding and gave them their own shelf. The clerk had but to point to the red-bound books when turned-on readers needing their next hit of exoticism and eroticism inquired. That shelf of "mysteries" has always fascinated me, for from that shelf's potent loins sprang first the romance novel, historical novel, and horror novel. Those commercial products, in turn, gave rise to the science fiction novel. And thus, in the 1970s, we watched Carrie Fisher locked up by her father in a huge castle - er, space station - and eventually rescued from her sado-masochistic torture by a naive farm boy and a knowing Byronic hero. In a nod to the changing times, the Space Princess with the secret past got to mock her rescuers a bit and even occasionally shoot a laser blaster: glorious feminist progress.

During the twentieth century these generic sons and daughters mixed with twentieth-century world politics: behold the rise of the spy novel. At that novel's core, it can be no surprise, there is still often a young, sexually tempting woman locked in a room kept there by sinister forces that reflect the biases and prejudices of the time. In the 
1790s Catholics provided the necessary villainy for a Protestant English reading public surrounded by Catholic Europe. In the 1960s, 1970s, and 1980s, it was communists who wanted to put an end to 007, democracy, NATO, and female decency. As readers, then and now, we await the pleasures of the virginal woman's escape and enjoy the sexual frisson of the exotic setting in the meantime.

Michelle Butler Hallett revisits many of these tropes in her historical spy novel Constant Nobody. The novel opens during the Spanish Civil War: a beautiful, young English aristocrat posing as a nurse and fluent in several languages - meets a young, handsome Soviet agent of the NKVD, a predecessor of the KGB. He is also posing as something that he is not and is also competent in a number of languages. She has a dead Russian mother in her past and can speak Russian more than competently. He's an orphan whose only imperfect language is English, it would seem, giving her a bit of power over him. His fake nurse provides real care for his gonorrhea before he fulfills his mission to assassinate the doctor she's working for. He really should kill her too, but, well, decides not to. It would seem he's fallen for the girl who can speak his mother tongue and look him in the eye and tell him his English is awful.

The scene shifts to Moscow, some years later. She has been sent as a spy because she speaks Russian. He has resumed life - after a grave injury in Spain - as an NKVD officer working in the middle of the Great Purge. She goes for a walk one day and finds herself abducted, drugged, and offered up as one of the featured sexual attractions of a quiet orgy for Russian bureaucrats and officers. He spots her at the party, naked and ripe for the raping. Instead of indulging his baser instincts - as he has done before - he takes her back to his Moscow apartment, claiming that he will help her escape to the British Embassy and in doing so risk his own life.

But her would-be rescuer quickly becomes a Gothic-style tormenter, taking care to lock the door of his flat every time he leaves. Much of Constant Nobody is spent in this locked Soviet 1930s apartment: the plot hinges on when and how our English aristocrat will 
leave. In one glorious moment, she does, and makes it as far as a subway station before she is met by her rescuer/would-be tormenter. The reader is asked to watch the apartment's lock - and the key in that lock - with morbid fascination. And we witness the development of the relationship between our Russian bear and our English rose. I'll leave you to digest the novel's latter half, lest I be accused of plot spoilers, and merely hint that the protagonists of most Gothic novels also had complicated relationships with identity and motivation.

Constant Nobody works. It rehearses - and I mean that in the most generous sense of that verb - the tropes of spy genre fiction with energy and verve. And yes, Hallett injects some much-needed ambiguity and questioning into these tropes - all too often misogynistic to their core - and implies a number of interesting and difficult questions. What does it mean for a capable girl or an orphaned boy to be rescued? Is it possible to rescue? What are the motivations of the rescuer? Is true escape even possible in a world separated by the paranoia shaped by the Cold War? The novel, I'm relieved to say, neither demonizes nor romanticizes Soviet life. NKVD agents are given to paranoia and corruption, yes, but the novel hints that our heroine's handlers back in England are no less paranoid, self-interested, and Machiavellian.

I might, however, have wished for a bit more at times. The story is well-researched and provoked an appetite for detail and a thicker historical context. Paranoia is competently invoked; I'm not sure its full narrative potential was realized. If our heroes are polyglots, perhaps more could be said about their identity in relationship to the chameleon linguistic skins they appear capable of putting on so easily? I could have used some banter about Russian adverbs, or the bizarre way English speakers signal the genitive case with a punctuation mark. And even at 400 plus pages, the novel's pacing was a bit rapid. If the past is a foreign country, let us stay a bit and get to know the locals.

Any historical novel always says more about the time that publishes it than it does about the time in which its action is set - Waverly was an attempt to seal England and Scotland's union with the modernity 
of the Hanover dynasty more than it was about the doomed Jacobite Rebellion of 1745-46. Recently, HBO's Chernobyl suggested — with winks that were anything but sly — that the United States might be in danger of falling prey to the kind of deep social ills that doomed the Soviet Union in the 1980s. Constant Nobody's ambiguity about the Cold War - the defining political reality of my childhood - was the most interesting thing about the novel. Here, Hallett seems to say, is this thing we fought over, fucked through, worried about, and thoughtlessly killed for. And in the end, the Cold War had no enduring reality: it was just another deadly, pointless game played by lecherous old men on an international stage for the benefit of their psychological and sexual stimulation. That thought might be more relevant than ever to an audience that has been driven half-mad as they watched the world's governments do little but flail and whine when a real threat appeared.

Nathan Elliott 